\title{
ANALISIS KUALITAS PELAYANAN YANG DIBERIKAN OLEH PEGAWAI ADMINISTRASI FAKULTAS EKONOMI DAN BISNIS (FEB) DITINJAU DARI KEPMEN PPAN NO.63 TAHUN 2003
}

\author{
I Putu Arya Dharmayasa ${ }^{1}$, Lulup Endah Tripalupi ${ }^{2}$ \\ Jurusan Pendidikan Ekonomi \\ Universitas Pendidikan Ganesha \\ Singaraja, Indonesia ${ }^{1,2}$ \\ e-mail: arya_pitoenk@yahoo.com¹, lulup_tripalupi@yahoo.com²,
}

\begin{abstract}
Abstrak
Penelitian ini bertujuan untuk mengetahui harapan dan perasaan mahasiswa di lingkungan FEB Undiksha berkaitan dengan kualitas pelayanan yang diberikan oleh pegawai administrasi, serta untuk mengetahui kualitas pelayanan yang diberikan oleh pegawai administrasi di lingkungan FEB Undiksha. Penelitian ini dilaksanakan di FEB Undiksha dengan jumlah responden sebanyak 110 orang. Data yang dikumpulkan dengan metode kuesioner, dianalisis dengan menggunakan rumus Servqual yaitu membandingkan setiap dimensi dan secara total yaitu persepsi pelanggan (perceived service) dengan pelayanan yang diharapkan pelanggan (expected service).

Hasil penelitian menunjukkan bahwa harapan mahasiswa baik secara total maupun perdimensi berada dalam kategori penting, sedangkan perasaan mahasiswa baik secara total maupun perdimensi berada dalam kategori cukup baik. Kualitas pelayanan secara total berada dalam kategori baik dengan skor 0,70, sedangkan kalau dilihat perdimensi, dimensi kesederhanaan memiliki skor sebesar 0,69 (kategori baik), dimensi kejelasan dan keterbukaan memiliki skor sebesar 0,69 (kategori baik), dimensi ketepatan waktu memiliki skor sebesar 0,62 (kategori cukup baik), dimensi akurasi memiliki skor sebesar 0,67 (kategori baik), dimensi keamanan memiliki skor sebesar 0,71 (kategori baik), dimensi efisien memiliki skor sebesar 0,71 (kategori baik), dimensi efektif memiliki skor sebesar 0,76 (kategori baik), dimensi ekonomis memiliki skor sebesar 0,72 (kategori baik), dan dimensi keadilan memiliki skor sebesar 0,73 (kategori baik). Walaupun kualitas layanan yang dilihat perdimensi dan secara total berada dalam kategori baik, tetapi masih adanya gap/kesenjangan antara harapan dengan apa yang dirasakan oleh mahasiswa. Hal ini mengindikasikan bahwa pelayanan yang diberikan pegawai administrasi FEB Undiksha belum sepenuhnya memenuhi harapan mahasiswa. Oleh karena itu masih diperlukan untuk melakukan beberapa perbaikan-perbaikan terkait dengan layanan administrasi yang diterima oleh mahasiswa.
\end{abstract}

Kata kunci: administrasi, kualitas pelayanan

\section{Abstract}

This research aims to determine the expectations and feelings of the students in the FEB Undiksha related to the quality of services provided by the administrative staff, as well as to determine the quality of services provided by the administrative staff at Undiksha FEB. This research was carried out in FEB Undiksha the number of respondents were 110 people. Data were collected by questionnaire, were analyzed by using a formula that compares each Servqual dimensions and total customer perceptions (perceived service) with customer service expected (expected service).

The results showed that the expectations of students either totally or dimensions are in a importal category, while the student feeling totally or dimensions are in a category quite well. Quality of service in total are in good category with a score of 0.70 , while judging dimensions, simplicity dimension has a score of 0.69 (good categories), the dimensions of clarity and openness has a score of 0.69 (good categories), timeliness dimension has a score of 0.62 (category quite well), dimensional accuracy scores of 0.67 (good categories), the security dimension has a score of 0.71 (good categories), efficient dimension has a score of 0.71 (good categories), the effective dimension has a score of 0.76 (good categories), the economic dimension has a score of 0.72 (good categories), and the dimensions of fairness has a score of 0.73 (good categories). Although the quality of service that is seen dimensions 
and in total are in good category, but there still exists a gap between the expectations with what is perceived by the students. This indicates that the service provided administrative officer FEB Undiksha not fully meet the expectations of students. Therefore, it is necessary to carry out some improvements related to administrative services received by students.

Keywords: administration, quality of service

\section{PENDAHULUAN}

Pendidikan di Indonesia diselenggarakan secara demokratis dan berkeadilan serta tidak diskriminatif dengan menjunjung tinggi hak asasi manusia, nilai keagamaan, nilai kultural, dan kemajemukan bangsa, dengan memberdayakan semua komponen masyarakat melalui peran serta dalam penyelenggaraan dan pengendalian mutu layanan pendidikan. Sesuai dengan Keputusan Menteri Pemberdayaan dan Penertiban Aparatur Negara Nomor 63 Tahun 2003, mengenai prinsip-prinsip pelayanan, seseorang yang bekerja sebagai pemberi pelayanan kependidikan atau sebagai tenaga kependidikan haruslah berpatokan pada hal-hal seperti kesederhanaan, kejelasan dan keterbukaan, ketepatan waktu, akurasi, keamanan, efesien, efektif, ekonomis, serta keadilan yang merata (Depdiknas, 2011).

Tjiptono (dalam Madihah, 2012) memaparkan ada tiga unsur utama pengelolaan pendidikan yaitu pendidik, tenaga kependidikan dan peserta didik. Pendidik merupakan tenaga profesional yang bertugas merencanakan dan melaksanakan proses pembelajaran, menilai hasil pembelajaran, melakukan pembimbingan dan pelatihan, serta melakukan penelitian dan pengabdian kepada masyarakat, terutama bagi pendidik pada perguruan tinggi. Tenaga kependidikan bertugas melaksanakan administrasi, pengelolaan, pengembangan, pengawasan, dan pelayan teknis untuk menunjang proses pendidikan pada satuan pendidikan. Peserta didik pada tingkat perguruan tinggi adalah mahasiswa. Peran tenaga kependidikan (pegawai administrasi) adalah untuk menciptakan suasana pendidikan yang bermakna, menyenangkan, kreatif, dinamis dan dialogis perlu didukung dengan adanya profesionalisme dalam melaksanakan tugasnya.

Perguruan tinggi adalah salah satu bentuk lembaga sosial formal yang memiliki hubungan eksternal dan polapola internal yang antara lain terlihat dari jalinan dengan stakeholdemya (Runtuwene, 2010). Hubungan eksternal dalam perguruan tinggi meliputi tiga hal, yakni (1) eksternal primer (para siswa), (2) eksternal sekunder (orang tua, para pemimpin pemerintahan dan perusahan), (3) eksternal tersier (pasar kerja dan masyarakat luas). Sedangkan pola-pola internal dalam perguruan tinggi terdiri dari dua hal, yakni secara psikis dan pisik. Secara psikis adalah bila mahasiswa diberi kesempatan untuk terus belajar dan mengembangkan kemampuan, bakat dan kreatifitasnya, sedangkan secara pisik adalah ketika mahasiswa mendapatkan imbalan dari ilmu yang diperolehnya di perguruan tinggi.

Oleh karena itu perguruan tinggi dituntut harus mampu memenuhi kebutuhan mahasiswa sehingga perguruan tinggi perlu meningkatkan kualitas melalui evaluasi didalam perguruan tinggi tersebut. Perguruan tinggi sebagai lembaga penyedia jasa pendidikan agar lebih peka terhadap kepentingan stakeholdemya, terutama stakeholder internal mahasiswa mereka yaitu mahasiswa sebagai asset terpenting perguruan tinggi. Untuk itu, peranan perguruan tinggi dalam hal ini fakultas sebagai bagian dalam perguruan tinggi yang secara langsung berhubungan dengan kegiatan mahasiswa tersebut dituntut untuk dapat memberikan pelayanan yang terbaik. Sejalan dengan itu Hamka (dalam Engkoswara, 2010) menyatakan bahwa faktor yang menentukan tingkat keberhasilan dan kualitas suatu perguruan tinggi adalah kemampuan lembaga tersebut dalam 
memberikan pelayanan yang bermutu dan berkualitas kepada mahasiswa. Banyak pengertian tentang kualitas pelayanan yang dikemukakan oleh para ahli, namun walaupun pengertian tersebut berbedabeda tetapi pada hakekatnya mempunyai makna yang sama. Menurut Ariani (2002:9) menyatakan kualitas merupakan bagaian dari semua fungsi usaha yang lain (pemasaran, sumber daya manusia, keuangan, dan lain-lain. Selain itu kualitas juga memerlukan suatu proses perbaikan yang terus-menerus (continuous improvement process) yang dapat diukur, baik secara individual, organisasi, korporasi, dan tujuan kinerja nasional. Menurut Kashmir (2005:31) "kualitas pelayanan diartikan sebagai tindakan atau perbuatan organisasi/ perorangan untuk memberikan kepuasan kepada pelanggan". Menurut Sugiarto (2002:39) "kualitas pelayanan adalah suatu penyajian produk atau jasa sesuai dengan ukuran yang berlaku di tempat produk tersebut diadakan dan penyampaiannya setidaknya sama dengan yang diharapkan pelanggan". Sejalan dengan pengertian para ahli tersebut, kualitas pelayanan pada dasarnya merupakan suatu kegiatan pelayanan yang diberikan kepada pelanggan sesuai dengan prinsip lebih mudah, lebih baik, cepat, tepat, akurat, ramah, dan sesuai dengan keinginan pelanggan. Tjiptono \& Diana (2003:2) menyatakan konsep kualitas pelayanan itu sendiri sering dianggap ukuran relatif kebaikan suatu produk atau jasa yang terdiri atas kualitas desain dan kualitas kesesuaian. Kualitas desain merupakan fungsi spesifikasi suatu produk atau jasa, sedangkan kualitas kesesuaian adalah suatu ukuran seberapa jauh suatu produk atau jasa memenuhi persyaratan atau spesifikasi kualitas yang telah ditetapkan

Oleh karena itu dalam rangka meningkatkan kualitas pelayanannya perguruan tinggi harus mengubah sikap dan peran dalam memberikan pelayanan. Perguruan tinggi secara terus menerus perlu meningkatkan layanan prima kepada masyarakat baik warga perguruan tinggi maupun masyarakat di luar perguruan tinggi. Pemberian pelayanan prima diharapkan dapat memberikan kepuasan terhadap pengguna jasa layanan. $\begin{array}{ccc}\text { Layanan } & \text { prima } & \text { yang } \\ \text { mengutamakan } & \text { prinsip efisiensi } & \text { dan }\end{array}$ produktivitas merupakan spesifikasi teknis tentang tolak ukur layanan minimum yang diberikan perguruan tinggi kepada masyarakat dengan mempertimbangkan kualitas layanan, pemerataan, kesetaraan layanan, biaya, serta kemudahan untuk mendapatkan layanan. Layanan administrasi yang seharusnya didapatkan oleh mahasiswa, misalnya layanan registrasi dan heregistrasi, pengisian rencana studi (KRS), surat menyurat yang berhubungan dengan perkuliahan dan tugas akhir, layanan seminar dan ujian tugas akhir, pencetakan transkrip nilai, dan Surat Keterangan Lulus (SKL), legalisir, dan yang lainnya. Besarnya tanggung jawab dalam layanan administrasi akademik, harus didukung oleh kompetensi sumberdaya manusia pelaksananya. Sejalan dengan itu (Suwena, 2011) menyatakan bahwa dalam memberikan layanan untuk memenuhi kebutuhan atau service mahasiswa yang dilayani tidak dapat lepas dari Sumber Daya Manusia (SDM). Oleh sebab itu SDM yang berkualitas harus memiliki kompetensi yang tinggi dan didukung sarana lainnya. SDM pelaksana layanan administrasi akademik pada perguruan tinggi adalah tenaga administrasi akademik yang ditugaskan pada bagian akademik di tingkat Perguruan Tinggi/ Fakultas/ Jurusan/ Program Studi/ unit kerja yang setara. Masih menjadi berbincangan dikalangan para ilmuan untuk mengukur tingkat kualitas dari sebuah layanan, oleh karena itu banyak para ahli mengemukakan pendapatnya untuk mengukur kualitas layanan itu sendiri. Menurut Ariani (2003) memaparkan ada sepuluh dimensi yang digunakan dalam mengukur kualitas suatu industri jasa, dimensi tersebut adalah (1) communication, (2) credibility, (3) security, (4) knowing the customer, (5) tangibles, (6) reliability, (7) responsiveness, (8) competence, (9) access, (10) courtesy. Tjiptono \& Diana (2003) menjelaskan ada delapan dimensi kualitas layanan yang dapat digunakan untuk mengukur kualitas pelayanan yaitu (1) kinerja (performance), (2) ciri-ciri keistimewaan tambahan (features), (3) kehandalan (reliability), (4) 
kesesuaian dengan spesifikasi (conformance to specifications), (5) daya tahan (durability), (6) serviceability, (7) estetika, (8) kualitas yang dipersepsikan (perceived quality). Menurut Lupiyoadi (2001), ada lima prinsip dimensi kualitas pelayanan yang digunakan untuk mengukur kualitas pelayanan yaitu (1) tangibles atau tampilan fisik, (2) reliability atau kehandalan, (3) responsiveness atau ketanggapan, (4) assurance atau jaminan, (5) empathy atau empati. Dalam penelitian ini dimensi yang akan digunakan adalah dimensi yang tertuang dalam Keputusan Menteri Pemerdayaan dan Penertiban Aparatur Negara nomor 63 tahun 2003 dalam kementrian pendidikan nasional (Depdiknas, 2011), karena penelitian ini berkaitan dengan dunia pendidikan khususnya di FEB Undiksha. Dimensi tersebut adalah (1) kesederhanaan, (2) kejelasan dan keterbukaan, (3) ketepatan waktu, (4) akurasi, (5) keamanan, (6) efesien, (7) efektif, (8) ekonomis, serta (9) keadilan yang merata.

\section{METODE}

Penelitian ini dilakukan pada Fakultas Ekonomi dan Bisnis Undiksha, pada prinsipnya penelitian ini merupakan penelitian evaluatif yang bertujuan untuk mengetahui nilai atau performance pelayanan administrasi akademik yang diberikan oleh pegawai di FEB, diukur melalui sembilan dimensi kualitas pelayanan prima yang tertuang pada Keputusan Menteri Pemerdayaan dan Penertiban Aparatur Negara Nomor 63 tahun 2003. Dimensi dari kualitas pelayanan yaitu kesederhanaan, kejelasan dan keterbukaan, ketepatan waktu, akurasi, keamanan, efesien, efektif, ekonomis, serta keadilan yang merata. Sedangkan desain deskriptif dalam penelitian ini digunakan untuk mendeskripsikan kualitas pelayanan yang diberikan pegawai administrasi pada FEB Undiksha.

Subjek dalam penelitian ini adalah mahasiswa FEB Undiksha sedangkan objek dari penelitian ini adalah kualitas pelayanan administrasi yang diberikan oleh pegawai FEB Undiksha. Populasi dalam penelitian ini adalah mahasiswa FEB sebesar 2.064 mahasiswa, Teknik sampling yang digunakan dalam penelitian ini adalah proportional random sampling, dengan penentuan proporsi tiap-tiap jurusan. Sampel mahasiswa sebesar 105 mahasiswa. Untuk memperoleh data yang diinginkan dalam penelitian ini, peneliti menggunakan metode (1) angket; (2) dokumentasi; dan (3) observasi.

\section{HASIL DAN PEMBAHASAN}

Berdasarkan data hasil penelitian yang dilakukan kepada 110 responden mengenai harapan mahasiswa terhadap pelayanan administrasi yang diberikan oleh pegawai FEB Undiksha, maka diperoleh hasil scoring baik secara total maupun perdimensi. Hasil penelitian mengenai harapan dan perasaan mahasiswa terhadap pelayanan administrasi yang diberikan oleh pegawai FEB Undiksha dapat dilihat pada tabel 1 dan 2 di bawah ini.

\section{Tabel 1 Harapan Mahasiswa Terhadap Pelayanan Administrasi Yang Diberikan Oleh} Pegawai FEB Undiksha

\begin{tabular}{clcl}
\hline No & \multicolumn{1}{c}{ Dimensi } & Skor & Kategori \\
\hline 1. & Kesederhanaan & 938 & Penting \\
2. & Kejelasan dan Keterbukaan & 611 & Penting \\
3. & Ketepatan waktu & 621 & Penting \\
4. & Akurasi & 615 & Penting \\
5. & Keamanan & 1.180 & Penting \\
6 & Efisien & 925 & Penting \\
7 & Efektif & 614 & Penting \\
8 & Ekonomis & 299 & Penting \\
9 & Keadilan Total & 624 & Penting \\
& & 6.427 & Penting \\
\hline
\end{tabular}


Tabel 2 Perasaan Mahasiawa Terhadap Pelayanan Administrasi Yang Diberikan Oleh Pegawai FEB Undiksha

\begin{tabular}{clcc}
\hline No & \multicolumn{1}{c}{ Dimensi } & Skor & Kategori \\
\hline 1. & Kesederhanaan & 648 & Cukup Baik \\
2. & Kejelasan dan Keterbukaan & 420 & Cukup Baik \\
3. & Ketepatan waktu & 384 & Cukup Baik \\
4. & Akurasi & 409 & Cukup Baik \\
5. & Keamanan & 837 & Cukup Baik \\
6 & Efisien & 659 & Cukup Baik \\
7 & Efektif & 469 & Cukup Baik \\
8 & Ekonomis & 216 & Cukup Baik \\
9 & Keadilan Total & 453 & Cukup Baik \\
\multicolumn{2}{r}{} \\
\end{tabular}

Berdasarkan hasil scoring Pada tabel 1 (table harapan mahasiswa), dan table 2 (table perasaan mahasiswa) menunjukkan bahwa harapan mahasiswa baik secara total maupun perdimensi berada dalam kategori penting, sedangkan perasaan mahasiswa baik secara total maupun perdimensi berada dalam kategori cukup baik.

Kualitas pelayanan administrasi
dapat diukur dengan cara

membandingkan dua faktor utama yaitu perasaan mahasiswa atas pelayanan administrasi yang nyata mereka terima (perceived service) dengan pelayanan administrasi yang sesungguhnya diharapkan/diinginkan (expected service). Hasil penelitian mengenai kualitas pelayanan administrasi yang diberikan oleh pegawai FEB Undiksha dapat dilihat pada tabel 3 di bawah ini.

Tabel 3 Kualitas Pelayanan Administrasi Yang Diberikan Oleh Pegawai FEB Undiksha

\begin{tabular}{clcccccc}
\hline No & Dimensi & Harapan & Perasaan & $\begin{array}{c}\text { Kualitas } \\
\text { Pelayanan }\end{array}$ & $\begin{array}{c}\text { Kualitas } \\
\text { Pelayanan } \\
(\%)\end{array}$ & Kategori & Gap \\
\hline 1. & Kesederhanaan & 938 & 648 & 0,69 & $69 \%$ & Baik & -290 \\
2. & $\begin{array}{l}\text { Kejelasan dan } \\
\text { Keterbukaan }\end{array}$ & 611 & 420 & 0,69 & $69 \%$ & Baik & -191 \\
3. & Ketepatan waktu & 621 & 384 & 0,62 & $62 \%$ & $\begin{array}{c}\text { Cukup } \\
\text { Baik }\end{array}$ & -237 \\
4. & Akurasi & 615 & 409 & 0,67 & $67 \%$ & Baik & -206 \\
5. & Keamanan & 1.180 & 837 & 0,71 & $71 \%$ & Baik & -343 \\
6 & Efisien & 925 & 659 & 0,71 & $71 \%$ & Baik & -266 \\
7 & Efektif & 614 & 469 & 0,76 & $76 \%$ & Baik & -145 \\
8 & Ekonomis & 299 & 216 & 0,72 & $72 \%$ & Baik & -83 \\
9 & Keadilan & 624 & 453 & 0,73 & $73 \%$ & Baik & -171 \\
& Total & 6.427 & 4.495 & 0,70 & $70 \%$ & Baik & -1.932 \\
\hline
\end{tabular}

Berdasarkan skor pada table di atas kualitas pelayanan secara total berada dalam kategori baik dengan skor 0,70 , sedangkan kalau dilihat perdimensi, dimensi kesederhanaan memiliki skor sebesar 0,69 (kategori baik), dimensi kejelasan dan keterbukaan memiliki skor sebesar 0,69 (kategori baik), dimensi ketepatan waktu memiliki skor sebesar 0,62 (kategori cukup baik), dimensi akurasi memiliki skor sebesar 0,67 (kategori baik), dimensi keamanan memiliki skor sebesar 0,71 (kategori baik), dimensi efisien memiliki skor sebesar 0,71 (kategori baik), dimensi efektif memiliki skor sebesar 0,76 (kategori baik), dimensi ekonomis memiliki skor sebesar 0,72 (kategori baik), dan dimensi keadilan memiliki skor sebesar 0,73 (kategori baik). Walaupun kualitas layanan yang dilihat 
perdimensi dan secara total berada dalam kategori baik, tetapi masih adanya gap antara harapan dengan apa yang dirasakan oleh mahasiswa. Hal ini mengindikasikan bahwa pelayanan yang diberikan pegawai administrasi FEB Undiksha belum sepenuhnya memenuhi harapan mahasiswa. Oleh karena itu masih diperlukan untuk melakukan beberapa perbaikan-perbaikan terkait dengan layanan administrasi yang diterima oleh mahasiswa.

Berdasarkan hasil penelitian mengenai pelayanan yang diberikan oleh pegawai administrasi Fakultas Ekonomi dan Bisnis (FEB) ditinjau dari Kepmen PPAN no.63 tahun 2003 dalam tabel 1 dan 2 secara total maupun perdimensi harapan mahasiswa berada pada kategori penting, sedangkan perasaan mahasiswa secara total maupun perdimensi berada pada kategori cukup baik. Untuk mengetahui harapan dan perasaan mahasiswa lebih mendalam pada tiap dimensi maka akan diuraikan sebagai berikut.

1) Dimensi kesederhanaan bisa diartikan sebagai kesederhanaan dalam tata cara atau prosedur pelayanan yang dilaksanakan semudah mungkin, dan tidak berbelit-belit sehingga memudahkan mahasiswa dalam menerima layanan yang diberikan oleh pegawai administrasi FEB Undiksha. Berdasarkan penelitian mengenai harapan mahasiswa, dimensi kesederhanaan memiliki skor 938. Besarnya skor tersebut mengindikasikan bahwa harapan mahasiswa akan dimensi tersebut penting, sedangkan untuk perasaan mahasiswa dalam dimensi ini berada pada skor 648, hal ini mengindikasikan perasaan mahasiswa akan kualitas pelayanan yang dilihat melalui dimensi kesederhanaan pegawai dalam memberikan pelayan terhadap mahasiswa masuk pada kategori cukup baik. Hal tersebut disebabkan karena masih adanya beberapa kendala yang belum bisa diatasi oleh pegawai seperti masalah dalam pengesahan KHS dan KRS yang hampir setiap semester selalu menjadi kendala dimana mahasiswa harus mengantri untuk mendapatkan gilirannya.

2) Dimensi kejelasan dan keterbukaan bisa diartikan sebagai kejelasan dan keterbukaan dalam menginformasikan prosedur dan tata cara dalam pemberian layanan agar mudah diketahui dan dimengerti oleh mahasiswa. Berdasarkan penelitian mengenai harapan mahasiswa, dimensi kejelasan dan keterbukaan memiliki skor 611. Besarnya skor tersebut mengindikasikan bahwa harapan mahasiswa akan dimensi tersebut penting, sedangkan perasaan mahasiswa untuk dimensi ini berada pada skor 648, hal ini mengindikasikan perasaan mahasiswa akan kualitas pelayanan yang dilihat melalui dimensi kesederhanaan pegawai dalam memberikan pelayan terhadap mahasiswa masuk pada kategori cukup baik. Hal tersebut disebabkan karena masih adanya beberapa kendala yang belum bisa diatasi oleh pegawai seperti masalah dalam pengesahan KHS dan KRS yang hampir setiap semester selalu menjadi kendala dimana mahasiswa harus mengantri untuk mendapatkan gilirannya.

3) Dimensi ketepatan waktu bisa diartikan sebagai ketepatan pegawai administrasi dalam penyelesaian tugas-tugasnya terutama yang berkaitan dengan layanan mahasiswa serta diselesaikan dalam kurun waktu yang telah dijadwalkan. Berdasarkan penelitian mengenai harapan mahasiswa, dimensi kesederhanaan memiliki skor 621. Besarnya skor tersebut mengindikasikan bahwa harapan mahasiswa akan dimensi tersebut penting, sedangkan perasaan mahasiswa untuk dimensi ini berada pada skor 384, hal ini mengindikasikan perasaan mahasiswa akan kualitas pelayanan yang dilihat melalui dimensi ketepatan waktu masuk kategori cukup baik. Hal tersebut lebih disebabkan karena walaupun masih adanya beberapa layanan-layanan yang tidak bisa diselesaikan tepat pada waktunya, seperti ketepatan waktu dalam penyelesaian 
permsalahan-permasalahan yang dihadapi oleh mahasiswa dan adanya beberapa pegawai yang sering terlambat datang ke kampus, serta faktor jaringan internet yang mandeg sering menyebabkan proses layanan menjadi terhambat, namun dari hasil sebaran kuesioner yang dilakukan oleh peneliti menunjukkan bahwa mahasiswa sudah merasakan cukup puas dengan kinerja pegawai administrasi yang dilihat dari dimensi ketepatan waktu.

4) Dimensi akurasi dapat diartikan sebagai produk pelayanan yang diterima oleh mahasiswa dapat diterima dengan benar, tepat dan sah. Berdasarkan penelitian mengenai harapan mahasiswa, dimensi kesederhanaan memiliki skor 615 . Besarnya skor tersebut mengindikasikan bahwa harapan mahasiswa akan dimensi ini penting, sedangkan perasaan mahasiswa dalam dimensi ini berada pada skor 409, hal ini mengindikasikan perasaan mahasiswa akan kualitas pelayanan yang dilihat melalui dimensi akurasi pegawai dalam menyelesaikan pekerjaan-pekerjaannya terkait tentang layanan yang diberikan kepada mahasiswa masuk kategori cukup baik. Hasil tersebut didapatkan dari sebaran kuesioner yang dilakukan oleh peneliti kepada mahasiswa, berdasarkan hasil dari sebaran kuesioner tersebut menunjukan bahwa mahasiswa sudah merasakan hal yang cukup baik, walaupun masih ada beberapa kekurangan yang dirasakan oleh mahasiswa terkait dengan layanan yang diberikan oleh pegawai, tetapi kekurangan tersebut tidak terlalu signifikan dirasakan oleh mahasiswa.

5) Dimensi keamanan bisa diartikan dalam proses pemberian layanan pegawai dapat memberikan rasa aman dan nyaman serta menjamin adanya kepastian hukum, selama proses layanan berlangsung. Berdasarkan penelitian mengenai harapan mahasiswa, dimensi kesederhanaan memiliki skor 1.180 . Besarnya skor tersebut mengindikasikan bahwa harapan mahasiswa akan dimensi ini penting, sedangkan perasaan mahasiswa dalam dimensi ini berada pada skor 837, hal ini mengindikasikan perasaan mahasiswa akan kualitas pelayanan yang dilihat melalui dimensi keamanan yang diberikan pegawai dalam memberikan layanan-layanan kepada mahasiswa masuk kategori cukup baik. Hal tersebut disebabkan karena dari hasil sebaran kuesioner terhadap mahasiswa menunjukkan bahwa sebagaian besar pegawai sudah memberikan penjelasan-penjelasan mengenai layanan yang akan diberikan, serta didukung pula dengan keterampilan-keterampilan yang dimiliki oleh pegawai sudah sesuai dengan bidangnya masing-masing, sehingga mahasiswa merasakan kepercayaan terhadap para pegawai dalam memberikan pelayanan kepada mahasiswa.

6) Dimensi efisien dapat diartika sebagai dalam pemberian layanan persyaratan yang diberikan haruslah hal-hal yang berkaitan langsung dengan pencapaian sasaran layanan, dengan tetap memperhatikan keterpaduan antara persyaratan dan produk layanan yang diberikan. Berdasarkan penelitian mengenai harapan mahasiswa, dimensi kesederhanaan memiliki skor 925. Besarnya skor tersebut mengindikasikan bahwa harapan mahasiswa akan dimensi ini sangat penting, sedangkan perasaan mahasiswa dalam dimensi ini berada pada skor 659, hal ini mengindikasikan perasaan mahasiswa akan kualitas pelayanan yang dilihat melalui dimensi efiesiensi yang diberikan oleh pegawai dalam memberikan layanan-layanan kepada mahasiswa masuk kategori cukup baik. Hal tersebut disebabkan karena dari hasil sebaran kuesioner terhadap mahasiswa menunjukan bahwa pelayanan yang dilakukan oleh pegawai administrasi sudah efisien. $\mathrm{Hal}$ tersebut dilihat dari ketelitian para pegawai dalam memberikan layanan terhadap mahasiswa, sehingga layanan yang diberikan bisa lebih efisien. 
7) Dimensi efektif bisa diartikan sebagai tidak adanya pengulangan pemenuhan kelengkapan persyaratan dalam konteks yang sama, baik dalam proses pelayanannya, maupun kelengkapan persyaratan yang disampaikan oleh pegawai administrasi. Berdasarkan penelitian mengenai harapan mahasiswa, dimensi efektif memiliki skor 614 . Besarnya skor tersebut mengindikasikan bahwa harapan mahasiswa akan dimensi ini penting, sedangkan perasaan mahasiswa dalam dimensi ini berada pada skor 469, hal ini mengindikasikan perasaan mahasiswa akan kualitas pelayanan yang dilihat melalui dimensi efiesiensi yang diberikan oleh pegawai dalam memberikan layanan-layanan kepada mahasiswa masuk kategori cukup baik. Hal tersebut disebabkan karena dari hasil sebaran kuesioner terhadap mahasiswa menunjukan bahwa pelayanan yang dirasakan oleh mahasiswa sudah efektif, misalnya dapat dilihat dari sudah berusahanya para pegawai untuk menghindari kesalahan sekecil apapun untuk mencegah terjadinya pengulanganpengulangan yang tidak diperlukan sehingga bisa membuat layanan menjadi lebih efektif.

8) Dimensi ekonomis bisa diartikan sebagai, dalam penetapan biaya pelayanan dilakukan secara wajar dengan memperhatikan jenis layanan yang diberikan serta tidak menuntut biaya terlalu tinggi diluar kewajaran, serta sesuai dengan peraturan yang berlaku baik itu di lembaga dan di fakultas. Berdasarkan penelitian mengenai harapan mahasiswa, dimensi ekonomis memiliki skor 299. Besarnya skor tersebut mengindikasikan bahwa harapan mahasiswa akan dimensi ini penting, sedangkan perasaan mahasiswa dalam dimensi ini berada pada skor 216, hal ini mengindikasikan perasaan mahasiswa akan kualitas pelayanan yang dilihat melalui dimensi ekonomisnya masuk kategori cukup baik. Hal tersebut disebabkan karena dari hasil sebaran kuesioner terhadap mahasiswa menunjukan bahwa pelayanan yang dilakukan oleh pegawai administrasi terhadap mahasiswa tidak adanya pemungutan biaya kecuali pengesahan ijasah yang masih dipungut biaya terhadap mahasiswa yang sudah tamat ketika mau mengesahkan ijasah dan nilainya.

9) Dimensi keadilan yang merata dapat diartikan sebagai, jangkauan pelayanan harus diusahakan seluas mungkin, distribusi yang merata dan perlakuan yang adil terhadap seluruh mahasiswa FEB. Berdasarkan penelitian mengenai harapan mahasiswa, dimensi keadilan memiliki skor 624. Besarnya skor tersebut mengindikasikan bahwa harapan mahasiswa akan dimensi ini penting, sedangkan perasaan mahasiswa dalam dimensi ini berada pada skor 453, hal ini mengindikasikan perasaan mahasiswa akan kualitas pelayanan yang dilihat melalui dimensi keadilan yang diberikan oleh pegawai dalam memberikan layanan-layanan kepada mahasiswa masuk kategori cukup baik. Hal tersebut disebabkan karena dari hasil sebaran kuesioner terhadap mahasiswa menunjukan bahwa pelayanan yang dilakukan oleh pegawai administrasi sudah cukup adil, dengan tidak adanya pembedaan antara mahasiswa yang satu dengan mahasiswa yang lainnya, serta para pegawai selalu mengutamakan kepentingan mahasiswa.

Berdasarkan hasil penelitian kualitas pelayanan dalam tabel 3 diperoleh perbandingan antara harapan dengan perasaan mahasiswa, hal tersebut menunjukkan kualitas pelayanan secara total atau pun perdimensi masuk kategori baik. Untuk mengetahui kualitas layanan yang diberikan oleh pegawai administrasi FEB Undiksha tiap dimensi maka akan diuraikan sebagai berikut.

1) Dimensi kesederhanaan memiliki skor 0,69 . Skor tersebut mengindikasikan kualitas pelayanan yang diberikan oleh pegawai administrasi dilihat dari dimensi kesederhanaan berada pada kategori baik. Namun untuk lebih memaksimalkan kualitas pelayanan, 
pegawai harus bisa lebih mempersiapkan diri dalam urusan KHS dan KRS yang menjadi agenda tetap setiap semester agar bisa berjalan lebih lancar dari sebelumsebelumnya.

2) Dimensi kejelasan dan keterbukaan memiliki skor 0,69. Skor tersebut mengindikasikan kualitas pelayanan yang diberikan oleh pegawai administrasi dilihat dari dimensi kejelasan dan keterbukaan berada pada kategori baik. Namun untuk lebih memaksimalkan kualitas pelayanan, pegawai harus bisa lebih terbuka dan memberikan penjelasan-penjelasan kepada mahasiswa terkait masalahmasalah dan pengumumanpengumuman yang berhubungan dengan mahasiswa.

3) Dimensi ketepatan waktu memiliki skor 0,62 . Skor tersebut mengindikasikan kualitas pelayanan yang diberikan oleh pegawai administrasi dilihat dari dimensi ketepatan waktu berada pada kategori cukup baik. Dari kesembilan dimensi yang diteliti, dimensi ini mendapatkan nilai yang paling kecil, hal tersebut disebabkan oleh beberapa faktor, seperti dalam penyelesaian permasalahanpermasalahan yang dihadapi mahasiswa, ketepatan waktu pegawai dalam menyelesaikan segala administrasi yang diperlukan mahasiswa dan ketepatan waktu pegawai dalam menyelesaikan pengesahan KHS dan KRS mahasiswa serta pegawai harusnya bisa lebih tepat waktu datang ke kampus.

4) Dimensi akurasi memiliki skor 0,67. Skor tersebut mengindikasikan kualitas pelayanan yang diberikan oleh pegawai administrasi dilihat dari dimensi akurasi berada pada kategori baik. Namun untuk lebih memaksimalkan kualitas pelayanan, pegawai harus bisa lebih sigap dalam penyelesaian tugas-tugasnya terkait masalah layanan, seperti harus lebih sigap dalam penyelesaian masalahmasalah yang diadapi mahasiswa.

5) Dimensi keamanan memiliki skor 0,71. Skor tersebut mengindikasikan kualitas pelayanan yang diberikan oleh pegawai administrasi dilihat dari dimensi keamanan berada pada kategori baik. Walaupun masuk kategori baik, namun sebaiknya pihak pegawai harus mampu untuk memberi jaminan pelayanan yang lebih baik. Pihak pegawai juga sebaiknya memberi kenyamanan dan keamanan yang lebih terjamin kepada mahasiswa.

6) Dimensi efisien memiliki skor 0,71. Skor tersebut mengindikasikan kualitas pelayanan yang diberikan oleh pegawai administrasi dilihat dari dimensi efisien berada pada kategori baik. Namun untuk lebih memaksimalkan kualitas pelayanan, pegawai harus bisa lebih bisa mengefisienkan prosedur-prosedur layanan dan lebih teliti dalam menyelesaikan setiap permasalahan, serta lebih cepat beradaptasi dengan aturan-aturan baru yang diterapkan oleh lembaga terkait dengan proses pemberian layanan terhadap mahasiswa.

7) Dimensi efektif memiliki skor 0,76. Skor tersebut mengindikasikan kualitas pelayanan yang diberikan oleh pegawai administrasi dilihat dari dimensi efektif berada pada kategori baik. Dengan skor yang sudah masuk kedalam katagori baik tersebut, pihak pegawai harus bisa menjaga kepercayaan dari mahasiswa, namum perlu diingat masih ada beberapa kekurangan yang perlu ditingkatkan lagi, seperti menghindari kesalahankesalahan yang tidak seharusnya dilakukan sehingga pelayanan yang diberikan bisa lebih efektif.

8) Dimensi ekonomis memiliki skor 0,72. Skor tersebut mengindikasikan kualitas pelayanan yang diberikan oleh pegawai administrasi dilihat dari dimensi ekonomis berada pada kategori baik. Dalam dimensi ini pegawai administrasi juga mendapatkan nilai yang cukup besar dalam pemberian layanannya kepada mahasiswa. Berdasarkan dari hasil sebaran koisiner menunjukakan bahwa hampir semua layanan yang 
diberikan tidak dipungut biaya oleh pihak pegawai.

9) Dimensi keadilan memiliki skor 0,73. Skor tersebut mengindikasikan kualitas pelayanan yang diberikan oleh pegawai administrasi dilihat dari dimensi keadilan berada pada kategori baik. Walaupun sudah berada dalam kategori baik, namun pihak pegawai harusnya lebih bisa mengutamakan kepentingan mahasiswa terlebih dahulu serta perlakuan terhadap mahasiswa bisa dilakukan seadil mungkin.

\section{SIMPULAN DAN SARAN}

Berdasarkan hasil penelitian dan uraian yang telah dibuat, maka dapat ditarik simpulan sebagai berikut.

(1) Harapan mahasiswa terhadap kualitas pelayanan yang diberikan oleh pegawai administrasi Fakultas Ekonomi Dan Bisnis (FEB) ditinjau dari Kepmen PPAN no.63 tahun 2003 secara total ataupun perdimensi berada pada kategori penting. Hal ini menggambarkan harapan mahasiswa sangat tinggi atas pelayanan yang ingin diperoleh dari pegawai administrasi FEB Undiksha.

(2) Kenyataan pelayanan yang dirasakan mahasiswa terhadap pelayanan yang diberikan oleh pegawai administrasi Fakultas Ekonomi Dan Bisnis (FEB) ditinjau dari Kepmen PPAN no.63 tahun 2003 secara total ataupun perdimensi berada pada kategori cukup baik. Hal ini mengindikasikan bahwa kualitas pelayanan yang selama ini mereka peroleh belum sesuai dengan harapan mereka.

(3) Kualitas pelayanan yang diberikan oleh pegawai administrasi Fakultas Ekonomi Dan Bisnis (FEB) ditinjau dari Kepmen PPAN no.63 tahun 2003 secara total berada pada kategori baik. Walaupun kualitas layanan yang dilihat secara total berada dalam kategori baik, tetapi masih adanya gap/kesenjangan antara harapan dengan apa yang dirasakan oleh mahasiswa. Hal ini mengindikasikan bahwa pelayanan yang diberikan pegawai administrasi FEB Undiksha belum sepenuhnya memenuhi harapan mahasiswa. Gap/ kesenjangan tersebut berada pada gap ke lima, dimana gap/kesenjangan ini terjadi karena adanya perbedaan persepsi antara pelayanan yang dirasakan dengan pelayanan yang diharapkan oleh pengguna layanan. Hal tersebut dapat dilihat masih adanya beberapa layanan yang diberikan pegawai administrasi FEB Undiksha dirasa kurang oleh mahasiswa. Sebagai contoh dalam pengesahan KHS dan KRS yang hampir setiap semester selalu menjadi kendala dimana mahasiswa harus mengantri untuk mendapatkan gilirannya, jaringan internet yang mandeg sehingga menyebabkan proses layanan menjadi terhambat. Selain itu masih adanya beberapa pegawai yang sering terlambat datang ke kampus sehingga proses layanan menjadi terganggu.

Berdasarkan hasli penelitian, dapat disarankan hal-hal sebagai berikut.

1) Diharapakan pihak pimpinan fakultas untuk menyediakan sarana dan prasarana seperti jaringan internet yang lebih memadai, sehingga nantinya akan bisa lebih menunjang dan melancarkan proses layanan yang diberikan oleh pegawai administrasi.

2) Pegawai diharapakan berada di kampus tepat pada waktunya sehingga proses layanan bisa berjalan dengan lancar. Masalah pembagaian waktu pada saat jam makan siang juga perlu menjadi perhatian khusus, supaya tidak terjadi kekosongan di kantor ketika jam makan siang, sehingga mahasiswa yang memerlukan layanan pada jam-jam tersebut tetap bisa dilayani. 
DAFTAR PUSTAKA

Ariani, Dorothea Wahyu. 2002. Manajemen Kualitas Pendekatan Sisi Kualitatif. Yogyakarta : Ghalia Indonesia.

Engkoswara, H. 2010. Administrasi Pendidikan. Bandung: Penerbit Alfabeta.

Kashmir. 2005. Etika Customer Service. Jakarta: PT. Raja Grafindo Persada.

Kementrian Pendidikan Nasional. 2011. Pelayanan Prima. Bojongsari Depok Pusat Pengembangan Tenaga Kependidikan.

Lupiyoadi, Rambat. 2001. Manajemen Pemasaran Jasa Teori dan Praktek. Jakarta: Salemba Empat.

Madihah, Azka. 2012. Analisis Kepuasan Mahasiswa Terhadap Kualitas pelayanan Pendidikan. Skripsi.
Tersedia pada

(http://blog.institutpertanianbogor.ac. id/azkamadihah/?p=24).

Runtuwene, Lastiko. 2010. Manajemen Berbasis Sekolah Sebagai Upaya Peningkatan Mutu Pendidikan. Jurnal. Tersedia pada (http://lastiko.multiply.com/journal/ite $\mathrm{m} / 1 /$ JOURNAL).

Sugiarto, Endar. 2002. Psikologi Pelayanan dalam Industri Jasa. Jakarta: PT. SUN.

Suwena. 2011. Evaluasi Pelayanan Administrasi Akademik Pada Universitas Pendidikan Ganesha Singaraja. Singaraja : Universitas Pendidikan Ganesha.

Tjiptono, Fandy dan Anastasia Diana. 2000. Manajemen Jasa. Edisi Kedua. Jakarta: Andy Offset. 